\title{
The use of common salt (sodium chloride) fortified with iron to control anaemia: results of a preliminary study
}

\author{
BY H. A. NADIGER, K. A. V. R. KRISHNAMACHARI, A. NADAMUNI \\ NAIDU, B. S. NARASINGA RAO AND S. G. SRIKANTIA \\ National Institute of Nutrition, Indian Council of Medical Research, Hyderabad-500007, \\ India
}

(Received 9 May I979 - Accepted I6 July 1979)

\begin{abstract}
I. Iron-deficiency anaemia continues to be a major public health problem in all developing countries. Fortification of commonly consumed food items has been suggested as an effective method of preventing anaemia. Common salt (sodium chloride) has been identified as a suitable vehicle to be fortified with Fe in India.

2. Common salt was fortified with ferric orthophosphate $(3500 \mathrm{mg} / \mathrm{kg})$ and sodium hydrogen sulphate $(5000 \mathrm{mg} / \mathrm{kg}$ ) to provide an additional $\mathrm{I} \mathrm{mg}$ elemental $\mathrm{Fe} / \mathrm{g}$ common salt consumed.

3. After ascertaining the acceptability of the fortified salt with respect to its colour, taste and bioavailability a pilot feeding trial was conducted among residential schoolchildren in Hyderabad. Feeding of the fortified salt for a period of I year resulted in a significant increase in the haemoglobin level of these children. There was also a significant reduction in the prevalence of anaemia among children given the fortified salt.

4. Before the same fortified salt is recommended as a public health measure to prevent Fe-deficiency anaemia among our population it is necessary that further large-scale community trials with this fortified salt are carried out particularly among the rural population.
\end{abstract}

Iron-deficiency anaemia continues to be a major public health problem in many developing countries including India. Results of previous surveys conducted in several parts of the world have indicated that the prevalence of anaemia ranges from $10 \%$ in adult men to 80\% in pregnant women (WHO, 1968; Cook et al. I971; Aung-Than-Batu et al. 1972; Yusufji et al. 1973; Murugan, 1974; WHO, 1975). However, a recent survey conducted by this Institute in Indian rural areas has indicated a high prevalence of anaemia even among adult men (National Institute of Nutrition, 1978). A public health programme to control anaemia in pregnant women and preschool children through supplementation of iron and folic acid tablets has been initiated in our country. Although no systematic evaluation has so far been done, it appears to have met with little success due to several operational reasons (Nutrition Society of India, 1973).

Fortification of food with Fe has been suggested as an effective method for the prevention of anaemia (WHO, 1972). Several foods such as cereals, fish sauce and sugar have been used as the vehicle (Elwood et al. 1968; Garby \& Arekul, 1974; Viteri et al. 1975). More recently common salt (sodium chloride) has been considered to be a suitable vehicle for $\mathrm{Fe}$ in India. Ferric orthophosphate $(3500 \mathrm{mg} / \mathrm{kg})$ along with sodium hydrogen sulphate $(5000 \mathrm{mg} / \mathrm{kg})$ has been found to be satisfactory (Narasinga Rao \& Vijayasarathy, 1975). The bioavailability of Fe from this fortified salt when added to the diet was essentially similar to that from ferrous sulphate. Bioavailability did not alter on storage under hot humid conditions.

The fortified salt provides $\mathrm{I} \mathrm{mg}$ of elemental $\mathrm{Fe} / \mathrm{g}$ and at the estimated salt intake of $15 \mathrm{~g} / \mathrm{d}$ per head (Pasricha, I966) an additional $15 \mathrm{mg}$ elemental Fe/d would be available.

The absorption of Fe from cereal-based diets of the type habitually consumed in India varies between 0.03 and 0.05 (Hallberg et al. 1974 and Narasinga Rao, 1978). Indian diets contain approximately $20-25 \mathrm{mg} \mathrm{Fe} / \mathrm{d}$ and this together with fortified salt should meet the 
daily Fe requirement ( $1-\mathrm{I} \cdot 5 \mathrm{mg}$ ) of a normal adult man. Fe absorption would be higher in women and anaemic subjects who need higher amounts (Narasinga Rao, 1978).

The fortified salt was found to be acceptable with respect to its colour and taste when incorporated into diets cooked by traditional methods. However, before fortified salt can be recommended for prevention of anaemia on a public health scale, its effectiveness has to be established by community trials. A pilot study was therefore undertaken to assess the effect of feeding Fe-fortified salt on the haemoglobin status of residential urban schoolchildren in Hyderabad.

\section{MATERIALS AND METHODS}

A total of 1080 boys and 565 girls in the age-range $5^{-1} 5$ years were registered for this study. These children were inmates of four residential schools in Hyderabad, two of them being boys' schools and the other two girls' schools. In the case of boys' schools one was a 'certified school' for reforming juvenile criminals and the other was an orphanage. The socio-economic background of the inmates of both these schools was similar. The 'certified school' was chosen as experimental and the orphanage as the control school. In the case of girls' schools one was a 'certified school' and the other was a residential school. The inmates of the residential school came from families with a slightly better socio-economic background. The residential school was chosen as experimental and the 'certified school' as control.

Of these children 222 boys and I6I girls in the experimental schools and ninety-two boys and seventy-one girls in the control schools were followed for 1 year. Ninety-seven boys in the experimental school and fifty-four in the control school were followed up for a further period of 6 months.

The inmates of the school were not allowed to leave the school premises except with special permission. Thus all food eaten by the children came from the community kitchen run by the authorities of the school. There was therefore little scope for children to consume food from outside. Each school had a medical officer who attended to all minor ailments. It was ensured with their co-operation that no Fe or any other haematinics were given to these children during the study period.

Base-line values for haemoglobin ( $\mathrm{Hb}$ ) and packed cell volume (PCV) were obtained and the schools were supplied with unfortified crushed common salt for a period of I month to get the children and the cooks used to the salt. Fe-fortified salt was then supplied to the experimental schools while the use of unfortified salt was continued in the control schools. It was also ensured that no salt other than that supplied by the Institute was used during the entire period of the study. Hb and PCV estimations were carried out at 6,12 and 18 months after the introduction of fortified salt. Blood samples were collected during the morning.

\section{Hb estimation}

$\mathrm{Hb}$ was estimated by the cyanmethaemoglobin method using the filter-paper technique (National Institute of Nutrition, 1974). In the first 500 subjects, estimations were done on duplicate samples to determine the extent of variation. Thereafter, every roth sample was analysed in duplicate as a check on the method. The mean $( \pm \mathrm{SE})$ duplicate variation was found to be $3.5 . t 0.013 \mathrm{~g} / \mathrm{l}$.

\section{PCV estimation}

PCV was estimated by the micro-haematocrit technique (Dacie \& Lewis, 1975).

\section{Dietary Fe estimation}

The Fe content of the meals was determined three times during the study period of I year on five duplicate meal samples, collected from each school. Fe was estimated in these diets after wet digestion using the thiocyanate method (Oser, 1965). 


\section{Absorption of Fe}

Absorption of $\mathrm{Fe}$ from the fortified salt was determined in five children by the doubleisotope technique using the whole-body counter (Narasinga Rao \& Vijayasarathy, 1975).

\section{RESULTS AND DISCUSSION}

Analysis of the results revealed that the mean $( \pm \mathrm{SE}) \mathrm{Hb}$ level at the time of the base-line survey was $12 \mathrm{I} \pm \mathrm{I} \cdot 0 \mathrm{~g} / 1$ in the experimental boys and $123 \pm \mathrm{I} \cdot 9 \mathrm{~g} / \mathrm{l}$ in the control boys. These values were not statistically different from each other. For the purpose of this study, children with $\mathrm{Hb}$ values below I $20 \mathrm{~g} / \mathrm{l}$ were considered anaemic (WHO, I968). Based on this criteria the extent of anaemia was also found to be similar in both these groups of boys, prevalence rates of anaemia being $53.7 \%$ in the experimental and $42.7 \%$ in the control.

In the case of girls, however, the initial $\mathrm{Hb}$ level in the experimental group $(137 \pm \mathrm{I} \cdot 5 \mathrm{~g} / \mathrm{l})$ was higher than that in the control group $(\mathrm{I} 26 \pm \mathrm{I} \cdot 8 \mathrm{~g} / \mathrm{l})$. The prevalence rates of anaemia were also different in the two schools ( $15.5 \%$ for the experimental school, $33.8 \%$ for the control school). Because of certain logistic problems, the children (girls) matched for $\mathrm{Hb}$ level could not be used, and appropriate statistical methods were therefore used for comparing the values.

Results were analysed as follows: ( $\mathrm{I}$ ) comparison of mean $\mathrm{Hb}$ and PCV values at different periods of feeding the fortified salt by using the paired $t$ test for differences between initial and final values and Student's $t$ test for differences between experimental and control groups (Snedecor \& Cochran, 1967); (2) comparison of the increase in $\mathrm{Hb}$ between experimental and control groups at different levels of initial $\mathrm{Hb}$ values by Student's $t$ test (Snedecor \& Cochran, 1967); (3) comparison of the prevalence of anaemia before and I year after the introduction of the fortified salt by using the test of proportions (Snedecor \& Cochran, 1967) and (4) comparison of frequency distributions of $\mathrm{Hb}$ before and after the introduction of fortified salt.

When analysed using the previously mentioned methods, it was observed that at 6 months after the introduction of fortified salt, there was no significant change in the haematological status. However, at 12 months and 18 months in both boys and girls $\mathrm{Hb}$ levels had significantly increased in the experimental groups. In boys of the control group there was a small decrease. The increase in the experimental group was found to be statistically significant, when compared to that of the control group. There was however no difference between the increase observed at I 2 months as compared to the increase at I 8 months (Table I).

To overcome the difficulty of non-comparability of initial $\mathrm{Hb}$ values in girls they were classified according to their initial $\mathrm{Hb}$ level and comparisons made between experimental and control children within each $\mathrm{Hb}$ group. A similar analysis was carried out for the boys. The results of these analyses are shown in Table 2. The increase in $\mathrm{Hb}$ depended on the initial $\mathrm{Hb}$ level, and at each $\mathrm{Hb}$ level the response in the experimental group was significantly higher than that in the control group. It was also found that the reduction in $\mathrm{Hb}$ occurred only in children whose $\mathrm{Hb}$ level was over $120 \mathrm{~g} / \mathrm{l}$, the maximum reduction being observed in children whose $\mathrm{Hb}$ levels were $140 \mathrm{~g} / \mathrm{l}$ or more.

Prevalence rates of anaemia were compared before and I year after the introduction of fortified salt. The results are presented in Table 3 . In both boys and girls the reduction in the prevalence of anaemia was significantly higher $(P<0.001$ and $P<0.01)$ in the experimental group. In the control group there was no statistically significant change in prevalence rates. The frequency distribution of $\mathrm{Hb}$ values before and after the introduction of salt is shown in Fig. I. A shift to the right was seen in the case of the experimental group as opposed to the control group, which remained essentially unaltered. Analysis of the PCV values yielded similar results. 
Table I. Effect of administration of fortified common salt (sodium chloride) on mean haemoglobin $(\mathrm{Hb})$ levels $(\mathrm{g} / \mathrm{l})$ in residential Indian schoolchildren

(Mean values with their standard errors)

\begin{tabular}{|c|c|c|c|c|c|c|c|c|c|}
\hline \multirow{3}{*}{$\begin{array}{l}\text { Period of } \\
\text { study } \\
\text { (months) }\end{array}$} & \multirow[b]{3}{*}{ Group } & \multicolumn{5}{|c|}{$\mathrm{Hb}$} & & & \multirow{3}{*}{$\begin{array}{l}\text { Statistical significanc } \\
\text { of difference between } \\
\text { experimental and } \\
\text { control groups }\end{array}$} \\
\hline & & \multicolumn{3}{|c|}{ Initial } & \multicolumn{2}{|c|}{ Final } & \multicolumn{2}{|c|}{ Increase } & \\
\hline & & subjects & Mean & $\overrightarrow{\text { SE }}$ & Mean & SE & Mean & $\mathbf{S E}$ & \\
\hline 12 & $\begin{array}{l}\text { Boys } \\
\text { Experimental } \\
\text { Control }\end{array}$ & $\begin{array}{r}222 \\
92\end{array}$ & $\begin{array}{l}121 \\
123\end{array}$ & $\begin{array}{l}1.0 \\
1.9\end{array}$ & $\begin{array}{l}134 \\
120\end{array}$ & $\begin{array}{l}1 \cdot 0 \\
1.5\end{array}$ & $\begin{array}{c}14^{* * *} \\
-3 \cdot 9^{* *}\end{array}$ & $\begin{array}{l}0.9 \\
1.5\end{array}$ & $P<0.001$ \\
\hline & $\begin{array}{l}\text { Girls } \\
\text { Experimental } \\
\text { Control }\end{array}$ & $\begin{array}{r}161 \\
71\end{array}$ & $\begin{array}{l}137 \\
126\end{array}$ & $\begin{array}{l}1.5 \\
1.8\end{array}$ & $\begin{array}{l}148 \\
131\end{array}$ & $\begin{array}{l}1 \cdot 1 \\
1 \cdot 9\end{array}$ & $\begin{array}{c}11 * * * \\
5^{* *}\end{array}$ & $\begin{array}{l}1.5 \\
1.8\end{array}$ & $P<0.02$ \\
\hline 18 & $\begin{array}{l}\text { Boys } \\
\text { Experimental } \\
\text { Control }\end{array}$ & $\begin{array}{l}97 \\
54\end{array}$ & $\begin{array}{l}119 \\
125\end{array}$ & $\begin{array}{l}2.2 \\
2.8\end{array}$ & $\begin{array}{l}134 \\
125\end{array}$ & $\begin{array}{l}1 \cdot 5 \\
2 \cdot 4\end{array}$ & $\begin{array}{c}15^{* * *} \\
-0.5 \mathrm{NS}\end{array}$ & $\begin{array}{l}1 \cdot 7 \\
2 \cdot 32\end{array}$ & $P<0.001$ \\
\hline
\end{tabular}

NS, not significant.

$* P<0.05, * * P<0.01, \quad * * * P<0.001$.

Fe absorption from the fortified salt was determined in a small group of five children at the end of the study. All the children had normal $\mathrm{Hb}$ values at the time of this determination. The mean Fe absorption in these children was found to be 0.034 (Table 4). This value is similar to that reported previously from this Institute and obtained with cereal-based diets (Narasinga Rao, 1978).

The Fe content of the diet in the control schools was found to be $20-25 \mathrm{mg} / \mathrm{d}$ and in the experimental school $35-40 \mathrm{mg} / \mathrm{d}$, which included Fe contributed by the Fe-fortified salt.

The reduction in $\mathrm{Hb}$ in the control group could not be traced to any episode of infection occurring during the course of the study. The possibility that the change from the home diet of these children to the school diet was a possible cause of the observed fall was considered. To test this possibility, children (boys) with more than $\mathrm{I} 30 \mathrm{~g} \mathrm{Hb} / \mathrm{l}$ were registered immediately after their admission into these schools and were followed for a period of 6 months. It was observed that children with higher $\mathrm{Hb}$ values $(>130 \mathrm{~g} / \mathrm{l})$ showed a reduction, similar to that observed earlier, within 2 months (from $146 \pm 2.28$ to $133 \pm 2.47$ in one school and from $13^{8} \pm 1 \cdot 31$ to $128 \pm 1 \cdot 82$ in the other school) of admission and maintained at that level subsequently. This observation was made in both groups, which had been divided previously into experimental and control groups. However, it was interesting to note that when the children were on fortified salt such a fall did not occur even in those who had high levels of $\mathrm{Hb}$. This suggests that Fe-fortified salt not only helped to improve the $\mathrm{Hb}$ level in the anaemic group but also helped to prevent a fall which would otherwise have occurred.

As pointed out earlier, many attempts have been made in different countries to fortify different food items with Fe. However, the results of tests to evaluate the efficacy of these programmes have been varied. Fe in the form of ferrous sulphate at a level of $10 \mathrm{mg}$ elemental Fe/individual per day was reported to be beneficial to prisoners in Mauritius (Stott, 1960). Similarly Fe in the form of FeNa-EDTA added to fish sauce to give I $\mathrm{mg}$ Fe per $\mathrm{ml}$ also produced a significant increase in PCV in Thailand (Garby \& Arekul, 1974). Even though fortification of wheat flour with $F e$ is in vogue in many Western countries, very few systematic studies have been carried out to evaluate the efficacy of these programmes (Baker \& DeMaeyer, 1979). Large-scale population studies in the UK (Elwood, 1968; Elwood et al. 197 I) 
Table 2. Change in haemoglobin $(\mathrm{Hb})$ levels $(\mathrm{g} / \mathrm{l})$ in residential Indian schoolchildren with different initial $\mathrm{Hb}$ values after feeding iron-fortified common salt (sodium chloride) for I year

(Mean values with standard errors; no. of subjects given in parentheses)

Hb level $\mathbf{g} / \mathbf{l} \ldots$

Group
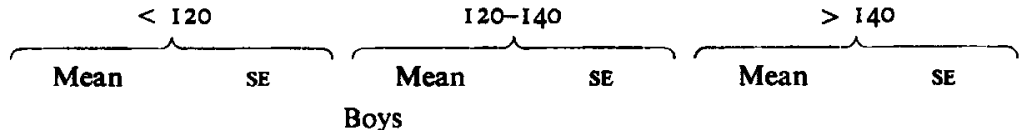

Experimental

Initial

Final

I08(II $\quad$ I 10

128(90)

0.5

140

$\begin{array}{ll}147(20) & 1.4 \\ 153 & 1.8\end{array}$

Differencet

$18^{* * *}$

$\mathbf{I} \cdot \mathbf{3}$

$12^{* * *}$

$1 \cdot 2$

$6^{* *} \quad 1 \cdot 8$

Control

Initial

Final

106(34) $2 \cdot 5$

II $\quad 2 \cdot 9$

$131(44) \quad 0.9$

I49(14) I.9

$124 \quad 1.5$

$13 \mathrm{I} \quad 2 \cdot 0$

Difference $\dagger$

$5 \cdot 0^{*} \quad 2 \cdot 5$

$-6 \cdot 0^{* * *}$

$-18^{* * *}$

$2 \cdot 9$

value for difference between experimental and control group $\dagger$

$4 \cdot 87^{* * *}$

$8 \cdot 59^{* * *}$

$3 \cdot 6 \mathrm{I}^{* *}$

Girls

Experimental

Initial

Final

104(25) $\quad 2.9$

I 37

$3 \cdot 7$

Difference $\dagger$

$32^{* * *}$

$4 \cdot 4$

Control

Initial

Final

Difference

$t$ value for difference

between experimental

and control groupt

$\begin{array}{ll}110(24) & 2 \cdot 3 \\ 120 & 3 \cdot 8\end{array}$

$11^{* *} \quad 3 \cdot 1$

$3 \cdot 93^{* * *}$

$\begin{array}{ll}130(54) & 0.8 \\ 146 & 1 \cdot 7\end{array}$

$16 * * * \quad 1.8$

129(37) 0.8

$135 \quad 2.0$

6**** 2-1

$3 \cdot 7^{* * *}$
$152(82) \quad I .0$

$153 \quad 1.0$

$0.9 \mathrm{NS} \quad \mathrm{I} \cdot 4$

$150(10) \quad 2 \cdot 4$

1403 . I

$-\mathrm{II}^{* * * *} \quad 3.5$

$2 \cdot 77^{* *}$

NS, not significant.

* $P<0.05,{ }^{* *} P<0.01, \quad * * * P<0.001, \quad * * * * P<0.02$.

$\dagger$ The mean differences within the groups were tested by using a paired $t$ test, while the differences between the control and experimental groups were tested using the Student's $t$ test.

Table 3. Percentage prevalence of anaemia* before and 1 year after the introduction of iron-fortified common salt (sodium chloride) to residential Indian schoolchildren

Group

Experimental

Control

Statistical significance of difference $†$

Experimental

Control

Statistical significance of difference $\dagger$
No. of subjects

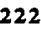

92

$16 \mathrm{I}$

71
Initial

Boys

$$
53 \cdot 7
$$

$42 \cdot 7$

NS

Girls

15.5

$33 \cdot 8$
Final

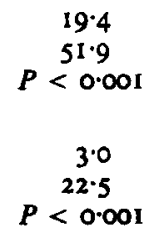

NS, not significant.

* Anaemia < I $20 \mathrm{~g}$ haemoglobin/l.

+ Analysis carried out using the test of proportions. 


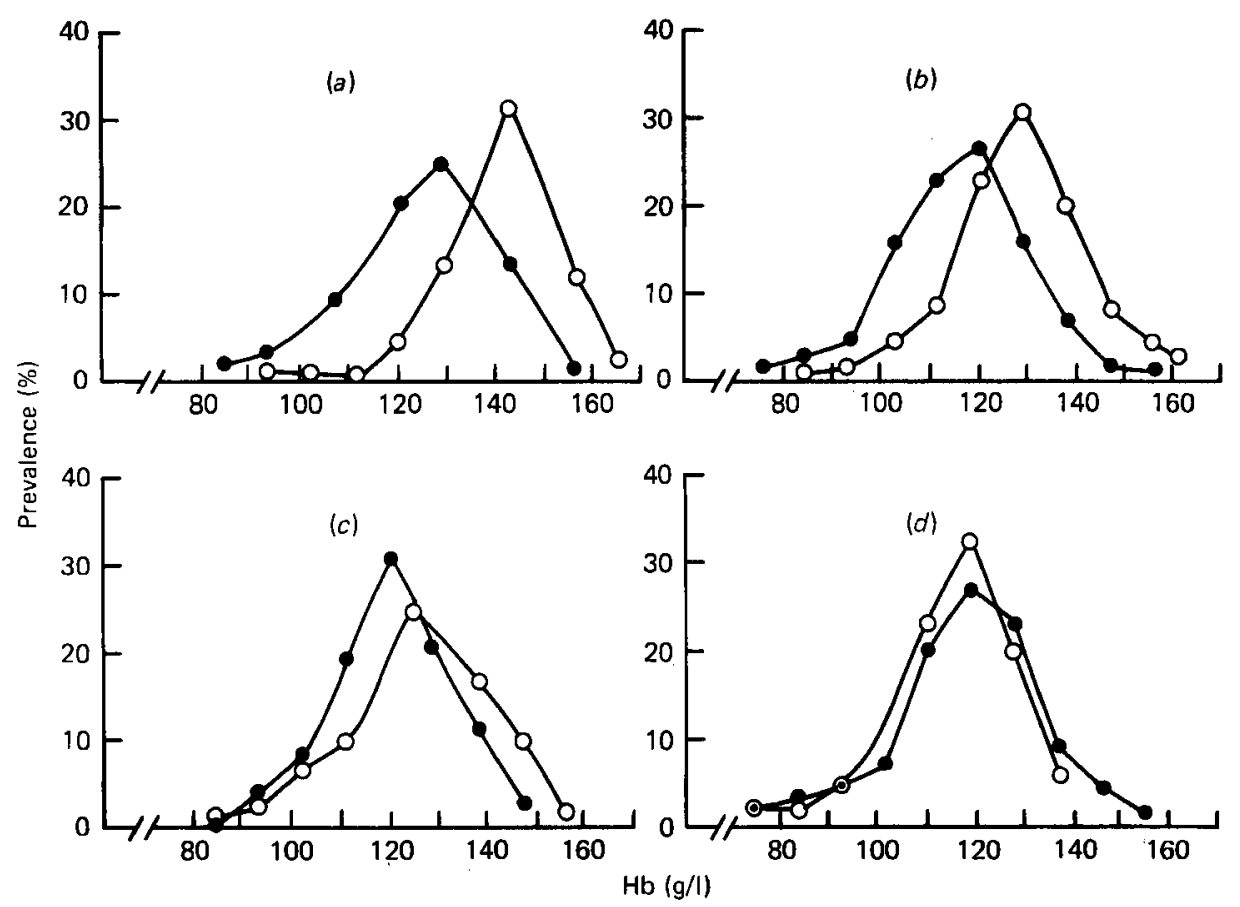

Fig. I. Frequency distribution of haemoglobin $(\mathrm{Hb})$ levels $(\mathrm{g} / \mathrm{l})$ in residential Indian schoolchildren before $(-\longrightarrow)$ and $\mathrm{I}$ year $(\mathrm{O}-\mathrm{O})$ after feeding iron-fortified common salt (sodium chloride). $(a)$, Girls, experimental; (b), boys, experimental; (c), girls, control; (d), boys, control.

Table 4. Iron absorption from Fe-fortified common salt (sodium chloride) in residential Indian schoolchildren

\begin{tabular}{ccrcc} 
& & \multicolumn{2}{c}{ Absorption } & \\
Subject no. & Haemoglobin $(\mathrm{g} / \mathrm{l})$ & ${ }_{{ }^{55} \mathrm{Fe} \text { salt }}$ & ${ }^{59} \mathrm{FeSO}$ & Fortified salt:FeSO \\
1 & 132 & 0.0485 & 0.1000 & 0.485 \\
2 & 128 & 0.0351 & 0.0220 & 1.594 \\
3 & 128 & 0.0421 & 0.0720 & 0.586 \\
4 & 123 & 0.0114 & 0.0420 & 0.272 \\
5 & 128 & 0.0328 & 0.0250 & 1.310 \\
Mean & 128 & 0.0340 & 0.0520 & 0.850
\end{tabular}

have however shown that consumption of Fe-fortified bread was not associated with any beneficial effect on haemoglobin status of the population. There may be two explanations for the failure to demonstrate any beneficial effect of some of the Fe-fortification programmes. One is the low level of Fe used for fortification. In the UK studies, bread was fortified at $35 \mathrm{mg} / \mathrm{kg}$ flour and additional intake of $\mathrm{Fe}$ through fortified bread was only $2 \cdot 7 \mathrm{mg} / \mathrm{d}$. In the present study, however, salt was fortified at a higher level of iron, i.e. $1000 \mathrm{mg} / \mathrm{kg}$, and additional intake of iron through fortified salt was $15 \mathrm{mg} / \mathrm{d}$. The other factor is the type of $\mathrm{Fe}$ used for fortification. The powdered reduced $\mathrm{Fe}$ used in the fortification of bread in the UK has been shown to be poorly absorbed from bread (Elwood, 1968). Iron in fortified salt on the other hand is absorbed as well as dietary iron. An additional factor operating in the present study is that the children studied here were a captive group 
and the daily intake of Fe-fortified salt by them was ensured, which was probably not the case with fortified bread in population studies reported from the UK (Elwood, 1968).

Based on the amount of salt obtained from the Institute it was found that the average per capita consumption of salt in these children was approximately $15 \mathrm{~g} / \mathrm{d}$. This value was reflected in the dietary $\mathrm{Fe}$ content. The mean increase in $\mathrm{Hb}$ observed over a period of $\mathrm{I}$ year ( $14 \mathrm{~g} / \mathrm{l}$ ) is well within the expected rise, as it accounts for approximately $70 \%$ of the $\mathrm{Fe}$ absorbed by these children, calculated on the basis of the observed absorption of 0.034 .

Throughout the study period of 1.5 years no untoward effect which could be traced to the intake of fortified salt was observed. There was no complaint from the children about the colour of the salt or the taste of foods prepared using fortified salt.

The results of the study thus demonstrate the beneficial effects of the use of Fe-fortified salt. It helped improve $\mathrm{Hb}$ levels in the anaemic group and prevented deterioration in children with normal $\mathrm{Hb}$ values. It must however be pointed out that the children studied were in an urban setting and do not represent people living in rural areas. Before the use of Fe-fortified salt can be recommended for the prevention of anaemia in the population, large scale community-based studies which include rural population have to be undertaken. Such studies have now been initiated at different centres in the country.

The authors wish to acknowledge the assistance received from the various officials of the Andhra Pradesh Government in conducting this study. They are also grateful to the superintendents of the schools for permitting them to carry out the investigation in their schools.

\section{REFERENCES}

Aung-Than-Batu, Hla-Pe, U., Thein-Than \& Khin-Kyi-Nyunt (1972). Am. J. clin. Nutr. $25,210$. Baker, S. J. \& DeMaeyer, E. M. (1979). Am. J. clin. Nutr. 32, 368.

Cook, J. D., Alvarado, J., Gutnisky, A., Jamra, M., Labardini, J., Layrisse, M., Linares, J., Loria, A., Maspes, V., Restrepo, A., Ryenafarje, C., Sanchez-Medal, L., Velez, H. \& Viteri, F. (1971). Blood 38, 591. Dacie, J. V. \& Lewis, S. M. (I975). Practical Haematology. 5 th ed. London: Churchill Livingstone.

Elwood, P. C. (1968). Proc. Nutr. Soc. 27, 14.

Elwood, P. C., Newton, D., Eaking, J. D. \& Brown, D. A. (1968). Am. J. clin. Nutr. 21 , I 62.

Elwood, P. C., Waters, W. E. \& Sweetnam, P. (1971). Clin. Sci. 40, 3 I.

Garby, L. \& Arekul, S. ( 1974). Ann. trop. Med. Parasit. 68, 467.

Hallberg, L., Garby, L., Suwanik, R. \& Bjorn-Ramussen, E. (1974). Am. J. clin. Nutr. $27,826$.

Murugan, S. (1974). Nutritional status of schoolchildren. MSc (Appl. Nutr.) dissertation, Osmania University.

Narasinga Rao, B. S. (1978). Indian J. Med. Res. 68, Suppl. 58.

Narasinga Rao, B. S. \& Vijayasarathy, C. (1975). Am. J. clin. Nutr. 28, 1395.

National Institute of Nutrition, Hyderabad (1974). Ann. Rep. natn. Inst. Nutr., Hyderabad.

National Institute of Nutrition, Hyderabad (1978). Ann. Rep. natn. Inst. Nutr., Hyderabad.

Nutrition Society of India (1973). Proc. Nutr. Soc. India 3, 30.

Oser, B. L. (1965). Hawk's Physiological Chemistry, I4th ed. New York: McGraw-Hill.

Pasricha, S. (1966). J. Nutr. Dietet. 3, 79.

Snedecor, G. W. \& Cochran, W. G. (I967). Statistical Methods, 6th ed. Ames, Iowa: Iowa State University Press.

Stott, G. (1960). Bull. Wld Hlth Org. 23, 781.

Viteri, F. E., Torun, B. \& Garcia. R. (1975). Ioth int. Congr. Nutr. Abstr. 82 I I.

WHO (1968). Tech. Rep. Ser. Wld Hlth Org. no. 405.

WHO (1972). Tech. Rep. Ser. Wld Hlth Org. no. 503.

WHO (1975). Tech. Rep. Ser. Wld Hlth Org. no. 580.

Yusufji, D., Mathan, V. I. \& Baker, S. J. (1973). Bull. Wld Hlth Org. 48, 15. 